\title{
Yerel Yönetimlerde Sosyo-Ekonomik Gelişmişlik Seviyeleri ile Hizmet Talebi Arasındaki İlişki: Antalya Muratpaşa Belediyesi Örneği
}

*

\author{
Nilüfer Gürer ${ }^{1}$ \\ ORCID: 0000-0001-5476-9382
}

\author{
Bengi Demirci2 \\ ORCID: 0000-0002-7515-4982
}

Öz

Çalışmanin amacı, vatandaşlar ile belediyeler arasındaki ilişkinin, sosyo-ekonomik ve teknolojik alandaki değişimlerden nasıl etkilendiğini araştırmak ve bu değişimin ayn belediye sınırları içerisinde yaşayan vatandaşlarm sosyo-ekonomik gelişmişlik durumlarnna göre değişiklik gösterip göstermediğgini, gösteriyorsa nasıl bir değişiklik gösterdiğini ortaya koymaktır. Çalışmada, vatandaşların belediyeden talep etmiş oldukları hizmetlerin içeriğinin ve talep yönteminin, onların sosyo-ekonomik gelişmişlik düzeyleri ile yakından iliş̧kili olduğu hipotezinden yola çıkılarak, farkl sosyo-ekonomik gelişmişlik düzeyine sahip olan bölgelerdeki hizmet taleplerinin içerik, sayı ve yöntem olarak karşılaştırmalı biçimde analiz edilmesi hedeflenmişstir.

Araştırmada, Antalya Muratpaşa Belediyesi sintrlarn içerisinde yaşayan vatandaşların belediyeden yapmiş olduklar hizmet talepleri ve bunları talep etme yöntemleri dört farkl sosyo-ekonomik gelişmişlik grubuna göre değerlendirilmiştir. Bu kapsamda vatandaşlarm taleplerinin içeriği ve bu taleplerini Belediye'ye iletme yöntemlerine ait veriler frekans dağılımlarına baktlarak analiz edilmiştir.

Elde edilen sonuçlara göre, vatandaşların sosyo-ekonomik gelişmişlik seviyeleri arttıkça belediyelerden yapmış oldukları hizmet taleplerinin de arttı̆̆̆ ve talep yöntemi olarak da çağrı merkezi ve başvuru masasının ilk sirada yer aldı̆̆ tespit edilmiştir. Vatandaşların belediyeden yapmış oldukları taleplerin içeriğine bakıldığında ise, çevre ve sosyal yardım konularını öne çıktı̆̆ı görülmekle beraber, günümüz kentlerinde sıkça karşılaşılan ekonomik ve sosyal değişimlerin (tüketim toplumu, yaşlanan toplum vb.) ve bunların sonucu olarak ortaya çıkan taleplerin de yerel yönetimlere iletildiği açıkça görülmektedir.

Anahtar Kelimeler: Yerel yönetimler, Belediye hizmetleri, Sosyo-ekonomik gelişmişlik

\footnotetext{
${ }^{1}$ Doç. Dr., Akdeniz Üniversitesi, E-mail: nilufergurer@gmail.com

${ }^{2}$ Dr. Öğr. Üyesi, Akdeniz Üniversitesi E-mail: bengidemirci@gmail.com

idealkent @ Kent Araştırmaları Dergisi (Journal of Urban Studies) 


\title{
The Relation Between Socio-Economic Development Level and Service Demand in Local Governments: The Case of Muratpasa Municipality of Antalya Province
}

\author{
Nilüfer Gürer ${ }^{3}$ \\ ORCID: 0000-0001-5476-9382
}

\author{
Bengi Demirci 4 \\ ORCID: 0000-0002-7515-4982
}

\begin{abstract}
The aim of this study is to understand how the relationship between the citizens and the municipalities are affected by socio-economic and technological changes and to analyze whether the effect of these changes differ due to socio-economic development levels. In this regard, this study analyzes the type, quantity and method of interaction in the service demands made from the municipality according to different socio-economic development levels in the same municipal area.

In this research, service demands made by the residents from the Muratpasa Municipality (Antalya) and their way of expressing these demands are analyzed according to four different socioeconomic development zones. Frequency distribution of the data on the content/type of the demands of the residents and of the data on the method they prefer to communicate these demands are examined.

Findings show that the number of demands made by the citizens increase as their socio-economic development level increases. Call center and information desk are the two most preferred/used channels for contacting the Municipality. While demands about environmental and social support issues are ranking high, it is seen that demands resulting from the frequently encountered economic and social urban changes (e.g. consumer society, ageing communities) are passed onto the local governments.
\end{abstract}

Keywords: Local government, Municipal services, Socio-economic development

\footnotetext{
${ }^{3}$ Assoc. Prof., Akdeniz University, E-mail: nilufergurer@gmail.com

${ }^{4}$ Assist. Prof., Akdeniz University, E-mail: bengidemirci@gmail.com
} 


\section{Giriş}

Bilgi ve iletişim teknolojilerindeki gelişmeler ve içinde olduğumuz küreselleşme süreci hem yerel yönetimlerden talep edilen hizmetlerin içeriğini, hem de bunları talep etme biçimini etkilemektedir. Bu taleplerin ve sunulan hizmetlerin değişiminde, kentlerde yaşanan sosyo-ekonomik değişimler ve buna bağlı olarak ortaya çıkan işsizlik, yoksulluk, yaşı/genç nüfus dağılımı gibi konuların da etkisi göz ardı edilemez. Bu çerçevede, hizmet sunumunda ön planda olan yerel yönetim birimlerinden belediyelerin sunmuş olduğu ve onlardan beklenen klasik belediyecilik hizmetlerinin de değişmeye başladığı görülmektedir. Belediyeler artık klasik hizmetlerinin yanında, vatandaşlardan gelen talepler doğrultusunda yeni konularda da görev üstlenmek durumunda kalmaktadırlar. Bu açıdan bakıldığında, belli ölçülerde değişikliğe uğramakla beraber, sosyal belediyecilik uygulamalarının önemli ölçüde belediyelerin gündeminde olmaya devam ettiğini görmekteyiz. Yine bu kapsamda günümüz koşullarında gelişen bilgi ve iletişim teknolojilerinin 1ş1ğında, belediye-vatandaş ilişkilerinde, gelen taleplere cevap verebilmek için, internet tabanlı iletişim yöntemlerinin kullanımında artış olması beklenmektedir.

Bu çalışmada, yukarıda kısaca özetlenmeye çalışılan hipotezlerin Antalya Muratpaşa Belediyesi özelinde test edilmesi amaçlanmış ve bu kapsamda vatandaşların belediyeden yapmış oldukları hizmet taleplerinin içeriği ve bu taleplerini belediyeye iletme yöntemleri, belediye sinurları içerisinde yaşayan vatandaşların sosyo-ekonomik gelişmişlik düzeyleri göz önüne alınarak incelenmiştir. Vatandaşlarla olan iletişiminde klasik yöntemlerin yanında daha güncel ve dijital yöntemleri sistemine entegre etmeyi deneyen bir yerel yönetim birimi olan Antalya Muratpaşa Belediyesi örnek çalışma alanı olarak seçilmiştir. Belediye, sahip olduğu nüfus büyüklüğü açısından Antalya'nın ikinci en büyük belediyesidir.

Çalışmanın birinci bölümünde, belediyelerin sundukları kentsel hizmetlerdeki değişim incelenmiş, bu çerçevede Türkiye'deki belediyecilik anlayışının geçirdiği sürece değinilmiştir. İkinci bölümde, vatandaşların belediye ile iletişim kurmak/hizmet talebinde bulunmak için tercih ettikleri yöntemler üzerinde durulmuş ve bunların bilhassa bilgi ve iletişim teknolojilerindeki gelişmelerin etkisiyle ne şekilde dönüşüyor olduğu irdelenmiştir. Alan çalışmasını içeren üçüncü bölümde, örnek olarak incelenen Muratpaşa Belediyesi verilerine dayanılarak, belediyenin sunduğu hizmetlerin ve bunların talep 
edilme biçimlerinin sosyo-ekonomik gelişmişlik seviyelerine göre değişip değişmediği sorgulanmıştır. Sonuç bölümünde ise güncel gelişmelere ve değişimlere cevaben belediyelerin sundukları hizmetler ve bunları sunma biçimleri değerlendirilmiş ve ileriye yönelik öneriler geliştirilmeye çalışılmıştır.

\section{Yerel Yönetim Hizmetlerindeki Değişim}

Kamu hizmetlerinin sunumunda halka en yakın birimler olarak görülen yerel yönetimlerin yerel halkın mahalli müşterek ihtiyaçlarını karşılamaya yönelik hizmetleri sunması hem dünyada hem de ülkemizde uzunca bir süredir yerleşmiş olan bir anlayıştır. Kamu hizmetlerinin "tercihen vatandaşa en yakın olan makamlar" tarafından yerine getirilmesini öngören Avrupa Yerel Yönetimler Özerklik Şartı'na göre (Madde 4), yerel yönetimler "kamusal işlerin önemli bir bölümünü, kanunla belirlenen sınırlar çerçevesinde, kendi sorumlulukları altında ve yerel nüfusun çıkarları doğrultusunda düzenleme ve yönetme hakkı ve imkanına" sahiptirler (Madde 3) ve "yetki alanlarının d1şında bırakılmamış olan tüm konularda faaliyette bulunabilirler" (Madde 4) (Avrupa Yerel Yönetimler Özerklik Şartı, 1992).

En yaygın yerel yönetim türü olan belediyeler, kentte yaşayan halkın ortak ihtiyaçlarını giderecek kamu hizmetlerini/mallarını üreten kurumlar olarak tanımlanmaktadır (Tekeli, 1977, s.33; Tekeli, 2009, s.265-266). Belediyelerin, sınırları dahilinde yaşayan vatandaşlara, ödedikleri vergilerin karşılığı olarak bir takım hizmetleri sunmaları gerektiği mantığından hareketle ilgili hizmetlerin belediyeler tarafından verilmesi öngörülmektedir. Hizmetin vatandaşa en yakın olan birim tarafından sunulması, yerel ihtiyaçların daha çabuk tespit edilip hizmet sunumunun daha çabuk gerçekleştirilmesi, daha katılımcı bir yöntemin hayata geçirilmesi gibi yerinden yönetimin avantajlı yönlerinin üzerine kurulmuş olan bu yaklaşım belediyelerin hizmet sunumunun arka planını oluşturmaktadır.

Belediye hizmetleri denilince, belediye sınırları içerisinde yaşayan halkın mahalli müşterek nitelikte olan imar, altyapı, ulaşım, su ve kanalizasyon, atık yönetimi, parklar ve yeşil alanlar, itfaiye, mezarlık ve cenaze, zabıta, işyeri ruhsatlandırmaları ve denetimi, gıda denetimi ve halk sağlığı, eğitim, kültür vb. konularda ihtiyaç duydukları temel hizmetler akla gelmektedir.

Belediyelerin sundukları hizmetler belediyenin ekonomik ve yasal durumunun yanında coğrafi, tarihsel ve geleneksel özelliklerine göre de değişiklik gösterebilmektedir. Dolayısıyla, bu hizmetler ülkeden ülkeye hatta aynı ülke içerisinde bir belediyeden diğerine değişiklik gösterebilmektedir. Örneğin bir 
belediye deniz ulaşımı hizmeti sunuyorken, deniz kenarında bulunan bir diğeri bu hizmeti sunmayabilir. Ya da biri pasaportların verilmesi hizmetini yürütüyorken bir başka belediyenin böyle bir görevi olmayabilir. Bununla birlikte, yukarıda sayılan temel hizmet alanları evrensel ölçekte değerlendirildiğinde belediyeler tarafından sunulan temel/klasik hizmetler olarak ele alınabilirler.

Yine belediye hizmetlerinin sunum yöntemi de belediyeden belediyeye farklılık gösterebilir. Hizmetler doğrudan belediyeye bağlı bir birim tarafından sunulabileceği gibi üçüncü kişiler tarafından da sunulabilir. Çalışmanın kapsamını fazlasıyla genişleteceği için belediye hizmetlerinin sunum yöntemlerine çalışmada yer verilmeyecektir.

Türkiye özelinde bakıldığında, yukarıda özetlenen genel yaklaşımın geçerli olduğu bir belediye hizmetleri sunma modelinin bulunduğu görülmektedir. Gerek Anayasa, gerekse Belediye Kanunu ve ilgili diğer düzenlemeler ile uzunca bir süredir Belediyeler mahalli müşterek nitelikte olan kamu hizmetlerinin sunumunda önemli aktörler olarak varlıklarını sürdürmektedirler (T.C. Anayasası Madde 127; 5393 Sayılı Belediye Kanunu). Buradan çıarılabilecek tanıma göre, belediye "belde sakinlerinin mahalli müşterek nitelikteki ihtiyaçların karşılamak üzere kurulmuş olan, karar organları seçmenler tarafından seçilerek oluşturulan, idari ve mali özerkliğe sahip ve merkezi idarenin vesayet denetimine tabi olan kamu tüzel kişileridir" (Gözler, 2018, s.188).

Türkiye'de belediyelerin sundukları hizmetlere bakıldığında, açıç̧a herhangi bir yerde yazılmamış olsa da, gerek literatürde gerekse uygulamada yerleşmiş olan bir ayrım göze çarpmaktadır. Buna göre, belediyelerin görevlerinin "mecburi" ve "isteğe bağlı" görevler olarak iki gruba ayrıldı̆̆ görülmektedir. (Gözler, 2018, s.192; Şarbak, 2017, s.31; Türkiye Belediyeler Birliği [TBB], 2020) Genel kabul görmüş bu ayrımdan hareketle, 5393 sayılı Belediye Kanununu 14. Maddesinin a bendinde sayılan görevlerin belediyelerin mecburi görevleri olduğu, $\mathrm{b}$ bendinde sayılanların da belediyelerin isteğe bağlı görevleri olduğu kavramsallaştırılması yerleşmiştir.

Bu çerçevede belediyelerin mecburi görevleri şu şekilde özetlenebilir (Şarbak, 2017, s.31-39; TBB, 2020): İmar (kentlerin imar planların yapmak ve yapılaşmayı denetlemek), altyapı (kent içi yol, kaldırım, meydan ve parkların yapımı, bakımı ve onarımı), ulaşım (kent içi toplu ulaşım), su ve kanalizasyon (suyun kent içinde dağıtımı ve işletmesi, atık suyun arıtılması), atık yönetimi (atık su yönetimi, katı atıkların toplanması, ayrıştırılması, geri dönüşümü ve depolanması), parklar ve yeşil alanlar, yerel mimarinin korunması, itfaiye, 
mezarlık ve cenaze hizmetleri, işyerlerinin ruhsatlandırılması ve denetlenmesi. Mecburi görevler olarak sinıflandırılan bu hizmetlerin yanında, belediyeler yoksullukla mücadele, eğitim, kültür ve spor hizmetleri, sosyal yardımlar, beceri kazandırma ve meslek kursları, hastalara evde bakım hizmetleri, devlet okullarının yapım ve bakımı gibi hizmetleri de üstlenmektedirler (Şarbak, 2017, s.31-39; TBB, 2020).

Çalışmanın sonraki bölümlerinde, yapılan araştırma verileri üzerinden de tartışlacağı gibi, değişen sosyo-ekonomik ve teknolojik koşullar neticesinde hem belediyelerden talep edilen hem de belediyelerin üstlenmek durumunda kaldıkları hizmetlerde değişiklik olduğu gözlenmektedir. Dolayısıyla, burada sayılmış olan görevlere eklemeler/çıkarmalar yapılabildiği gibi belli hizmet alanlarına belli dönemlerde daha fazla veya daha az yoğunlaşıldığ görülmektedir.

Belediyelere birçok alanda farklı görevler vermiş olan Kanun, bu görevlerin yerine getirilmesinde öncelik sırasının belediyenin mali durumuna ve hizmetin ivediliğine göre belirleneceğini söylemektedir (Madde 14/3). Yine Kanuna göre belediyeler hizmetleri vatandaşlara en yakın yerde, en uygun yöntemle sunacaklar ve hizmetlerin sunumunda engelli, yaşlı, düşkün ve dar gelirlilerin durumuna uygun yöntemler uygulayacaklardır (Madde 14/4).

Belediyeler, birçok alanda yürütecekleri hizmetler için iç yapılanmalarını da düzenlemek durumundadırlar. Kanun, belediyelerin, nüfus, fiziki ve coğrafi yapı, sosyo-ekonomik ve kültürel özelliklerinin gerektirdiği biçimde uygun birimleri belediye meclislerinde alacakları kararlar ile kurabileceklerini belirtmiştir (Madde 48). Buna dayanarak belediyeler fen işleri, zabıta gibi temel hizmet birimlerinin yanında, sözü edilen durumlara cevaben gerekli hizmetleri sunabilmek için kendi içlerinde farklı hizmet birimleri oluşturabilmektedirler. Bunun sonucunda da farklı belediyelerde, temizlik işleri müdürlüğünden kreş müdürlüğüne uzanan farklı hizmet birimlerinin faaliyet gösterdiği izlenmektedir.

Türkiye'de belediyelerin yürüttükleri kentsel hizmetler genel itibarnyla yukarıda anlatılan genel çerçevede sürdürülmüş olmakla beraber, söz konusu hizmetlerin içeriği ve kapsamında, yaşanan sosyo-ekonomik gelişmelerin de etkisiyle dönemsel olarak değişiklikler olmuştur. Nüfusun az, kentleşmenin yavaş olduğu Cumhuriyetin ilk yıllarında halk sağlığı, imar, altyapı, sosyal yardım ve nüfusu artırmaya yönelik hizmetler belediyelerin görevleri arasında ön plana çımaktaydı (Tekeli, 1977, s.33; Tekeli, 2009, s.32, 41). Burada elbette farklı alanlarda izlenen devlet politikaları, siyasi konjonktür vb. 
faktörlerin etkili olduğu da not edilmelidir. İkinci Dünya Savaşı sonrası dönemde yaşanan hızlı kentleşme ile belediyelerin ilgilenmek durumunda kaldıkları hizmet alanları çeşitlenmiş, trafik düzenlemesi, içme suyu, konut sorunu gibi konular ön plana çımaya başlamıştır. Planlı kalkınma dönemine geçilmesi ile birlikte belediyelerin ekonomik hayatı düzenlemeye yönelik görevler üstlenerek belli meslekler için ücret tarifeleri ve belli gida maddeleri için azami satış fiyatı belirleme görevlerini üstlendikleri ve denetim yetkilerini genişlettikleri görülmüştür (Tekeli, 2009, s.196-198). Türkiye'de 1970'li yıllarda gündeme gelen toplumcu belediyecilik anlayışı ile belediyelerin kamu malı/hizmeti sunmalarının yanında piyasa malları üretimi, konut/arsa üretimi gibi alanlara girmesi öngörülmüştür. Demokratik ve katılımcı olmanın yanı sıra belediyelerin sosyal adaletçi olmaları, üretici olmaları, tüketimi düzenlemeleri ve kaynak yaratmaları gerektiği üzerinde durulmuştur (Tekeli, 1977, s.33; Tekeli, 2009, s.252-255). 1980 sonrası dönemde belediyelerin yetkilerinde bir artış gözlenmiştir ve belediyelerin faaliyetlerinin özellikle imar ve altyapı projeleri konularında yoğunlaştığı görülmektedir (Şengül, 2001, s.109; Tekeli, 2009, s.279, 281). Bu dönem için yapılan yorumlardan biri de belediyelerin gerek kaynak yetersizliği gerekse artan vesayet denetimi neticesinde görev alanlarını merkezi yönetime bırakmak durumda kaldıkları yönündedir (Tekeli, 2009, s.294-298). Bir diğer değerlendirme de, önceki dönemin, emeğin yeniden üretimini merkeze alan kentsel hizmet sunumu modelinin, bu dönemde yerini sermayenin yeniden üretimini merkeze alan kent girişimciliğine dayalı hizmet sunma modeline bıraktı̆̆ı̆ır (Şengül, 2001, s.108). Sonraki dönemde iyice ağırlı̆̆ını hissettirmeye başlayan küreselleşmeyerelleşme dinamikleri, teknolojik gelişmeler, küresel ölçekte rekabet eden kentler olgusu ve bunların kentler ve kentlerde yaşayanlar üzerindeki etkileri de belediyelerin sundukları hizmetler üzerinde etkili olmaktadır. Bu çerçevede söz gelimi meslek edindirmeye ve istihdama yönelik veya bilgisayar kullanımına yönelik kurs hizmetlerinin belediyeler tarafından sunulduğu görülmektedir.

Değişen teknolojik, demografik, sosyo-ekonomik, siyasi, kültürel vb. koşulların belediye hizmetlerini belirgin bir biçimde etkilediği görülmektedir. Bu etki neticesinde, hem vatandaşların belediyelerden talep ettikleri hem de belediyelerin sundukları "klasik" belediye hizmetlerinin yanında, enerji, çevrenin korunması, yetişkinlerin eğitimi, özelleştirilmiş sosyal hizmetler (belli hastalıklara yönelik hizmet talepleri gibi), istihdam vb. konulardaki hizmet talepleri/sunumu ön plana çıkarmaya başlamıştır. Örneğin, çevre bilincinin gelişmesiyle birlikte gerek vatandaşların yerel yönetimlerden talep ettikleri, 
gerekse yerel yönetimler tarafından hayata geçirilen geri dönüşüm projelerinin arttı̆̆ görülmektedir. Ya da tüketim toplumu olma yolunda hizla ilerlemenin bir yansıması olarak kentlerde, yerel yönetimlere daha fazla evden atık eşya toplanması talebi geldiği görülmektedir. Toplumda artan sağlıklı yaşam bilincine paralel olarak vatandaşların belediyelerden daha fazla spor sahası, spor kursları ya da açık yeşil alan talep ettikleri gözlenmektedir. Yine benzer bir şekilde, yaşlanan nüfus ve yaygınlaşmaya başlayan belli hastalıklar, belediyelerden bu hastalıklara ve yaşlılara yönelik evde bakım, yaşlı kreşi gibi hizmetlerin talep edilmesine yol açmaktadır. Bir başka örnek, işsizliğin arttığ dönemlerde belediyelerden talep edilen meslek edindirmeye yönelik kursların sayısındaki artış olabilir. Belediye hizmetlerindeki (belediyelerin sunduğu hizmetlerin içeriğindeki) bu tip değişimler, dünyada olduğu gibi Türkiye özelinde de gözlemlenmektedir. Konuyla ilgili, özel olarak belediye örneklerine bakarak bu değişimi görebilmek vakalar bazında olanaklı olsa $\mathrm{da}^{5}$ henüz kapsayıcı literatür çalışmaları bulunmamaktadır. Bu araştırmanın alandaki çalışmalara bu yönden de katkı sağlaması umulmaktadır.

\section{Yerel Yönetimlerle İletişim ve Hizmet Talebi}

Yönetişim kavramı, yerel yönetimler açısından dünya literatüründe öne ç1kan temel kavramlardan birisidir. Şeffaflık, hesap verebilirlik, katılım, eşitlik, etkinlik, verimlilik gibi temel kavramların merkeze alındığı bu yönetim anlayışı, farklı aktörlerin biraradalığını dikkate alan, toplumun farklı kesimlerine karar alma süreçlerine katılma ve söz söyleme imkânı sunan bir yönetim biçimi olarak da tanımlanabilir (Ruige, Üskent ve Micka, 2014, s.11). Yapısı gereği iyi yönetişimin temelinde, yerel yönetimlerin vatandaşlar ile kurduğu ilişkinin de güçlü olması yer almaktadır.

21. yy.da hız kazanan bilgi ve iletişim teknolojilerinin gelişimi ve gündelik yaşama entegrasyonu sadece bireyler arası iletişim için değil, aynı zamanda vatandaşların resmi kurum ve kuruluşlar ile karşılıklı iletişimi, etkileşimi,

\footnotetext{
${ }^{5}$ Örneğin, Danimarka' da değişen sosyo-ekonomik koşullara paralel olarak belediyelerin üstlenmeye başladıkları hizmetler arasında çevrenin korunması, evde bakım, istismarın önlenmesi, terk edilmiş çocukların bakımı, göçmenlerin ve mültecilerin entegrasyonu gibi hizmetler sayılmaktadır (KL - Local Government Denmark, 2020).

Hollanda' da belediyelerin belediye sınırları içerisinde yaşayan vatandaşlara ait kişisel kayıtlardan oluşan veri tabanı tutulması, çevre yönetimi kanunun uygulanması, sosyal destek programlarının uygulanması gibi görevlere ağırlık verdiği görülmektedir (Government of the Netherlands, 2020)
} 
bilgi alışverişlerini ve hizmet taleplerini de etkilemektedir. Son dönemde yoğun bir biçimde kullanılan elektronik platformların ve özellikle de sosyal medya araçlarının farklı paydaşlar tarafından kullanılması, yerel yönetimleri de bu platformlarda yer almaya yönlendirmiştir.

Vatandaşların kamu kurum ve kuruluşlarından ve bu kapsamda yerel yönetimlerden de bilgi ve hizmet alabilmek için tercih ettikleri iletişim yöntemleri değişkenlik göstermektedir. Geleneksel yöntemler olarak tanımlanan yüz yüze görüşme, telefon ile görüşme ve yazılı iletişim kurma yöntemlerine, 1980'lerden sonra bilgi ve iletişim teknolojilerinin hızla gelişmesiyle, e-posta ve web sitesi gibi iki yeni (online) iletişim kanalı eklenmiştir (Ebbers, Pieterson ve Noordman, 2008, s.184; Reddick, Abdelsalam ve Elkadi, 2012, s.228).

Literatür araştırması, dünyada yerel yönetimlerin vatandaşlar ile iletişim kurarken, gelişen bilgi teknolojilerinin de desteği ile, hem interaktif iletişim sağlanabilmesi hem de bu iletişimin daha hızlı ve şeffaf olabilmesi için sosyal ağları da içeren şekilde, internet tabanlı iletişim yöntemlerine yöneldiklerini göstermektedir (Aji, Suroyya ve Dewi, 2017, s.2; Cohen, 2006, s. 52; Hofmann, Beverungen, Räckers ve Becker, 2013, s.388; Mahmood, Weerakkody ve Chen, 2019, s.2-3; Vivier, Seabe, Wentzel ve Sanchez, 2015, s.81) Bu noktada, internet tabanlı (online) iletişim yöntemlerinin vatandaşlar tarafından da tercih edilip edilmeyeceği önemli bir araştırma sorusudur.

Hükümetler, tıpkı özel sektörde olduğu gibi vatandaş etkileşimlerini çeşitli kanallardan yönetme ihtiyacı ile karşı karşıyadır. Geleneksel yöntemlerle hizmet sunumunun online kanallarla hizmet sunumundan daha maliyetli olduğu tespitinin üzerine, kamu kurum ve kuruluşları ve özelde de yerel yönetimler, bu konulara yönelik alternatif çözüm arayışlarına öncelikli hedefleri arasında yer vermektedirler (Plattfaut vd., 2013, s.1983; Pieterson, 2010, s.37). Online yöntemlerle hizmet sunumlarının yapıldığ durumlarda yine dünya literatüründe tartışılan bir önemli konu da dijital ayrışma (digital divide) konusudur. Yerel yönetimlerin hizmet sunduğu farklı sosyo-ekonomik gelişmişlik seviyesindeki vatandaşların, dijital platformlara eşit düzeyde erişimlerinin olup olmadığı önemli bir kriterdir. Demografik özellikler ve ekonomik gelir düzeyleri, kişilerin internet kullanım tercihlerini ve sıklığını belirlemekte (Plattfaut vd., 2013, s.1984; Reddick vd., 2012, s.232), bu ise kamu kurum ve kuruluşlarından hizmet taleplerini ve bu kurumlarla iletişim biçimlerinde tercih edecekleri yöntemleri seçmede etkili olmaktadır. Pieterson ve Ebbers tarafından yapılan bir araştırmada gelişmiş ülkelerde vatandaşların kamu kurum ve kuruluşları ile iletişim yöntemi olarak geleneksel yöntemleri tercih ettikleri, ilk üç sırada elektronik iletişim kanallarının yer almayıp bu 
sıralamayı telefon, yüz yüze görüşme ve yazılı iletişim yöntemlerinin oluşturduğu belirtilmiştir (Pieterson ve Ebbers, 2008, s.228). Bu bakış açısıyla, toplumun her kesimine hizmet eden yerel yönetimlerin gerekli kapsayıcılığı sağlayacak şekilde farklı iletişim kanallarını bir arada kullanmaları gerektiği açıktır.

\section{Muratpaşa Belediyesi'nde Sosyo-Ekonomik Gelişmişlik Seviyeleri ile Hizmet Talebi Arasındaki İlişki}

Araştırmada, Antalya Muratpaşa Belediyesi sınırları içerisinde yaşayan vatandaşların belediyeden yapmış oldukları hizmet talepleri ve bunları talep etme yöntemleri dört farklı sosyo-ekonomik gelişmişlik grubuna göre değerlendirilmiştir. Belediye sınırlarında yer alan mahallelere ilişkin sosyo ekonomik gelişmişlik grupları oluşturulurken Türkiye İstatistik Kurumu'nun (TÜIK) verileri temel alınmış, TÜİK çalışmaları ile benzer olarak, çalışma alanı için dört farklı gelişmişlik durumu belirlenmiştir (A: çok gelişmiş, B: gelişmiş, C: az gelişmiş, D: gelişmekte olan).

Çalışmada kullanılan hizmet taleplerinin içerik ve talep edilme yöntemlerine ilişkin veriler, 2018 yllına ait olup, Muratpaşa Belediyesi'nden temin edilmiştir. Söz konusu veriler vatandaşların Muratpaşa belediyesine farklı yöntemlerle ulaşarak ilettikleri taleplerinin belediye görevlilerince ilgili birimlere (müdürlüklere) iletilmek üzere kayıt altına alınması sonucu elde edilen verilerdir. Veri toplama sırasında gerçekleşmiş olabilecek hatalı sınıflandırma, kodlama, yönlendirme vb. durumlar çalışmanın kısıtlılığı olarak değerlendirilebilir.

Vatandaşların taleplerinin içeriği ve bu taleplerini Belediye'ye iletme yöntemlerine ait veriler frekans dağılımları ele alınarak değerlendirilmiştir. Belediyeden talep edilen hizmetlerin içeriğinin ve talep edilme yöntemlerinin sosyo-ekonomik gelişmişlik düzeyine göre ne şekilde değiştiği analiz edilirken, tüm birimlere gelen toplam talep sayısı ilçe belediyesi nüfusu (2018 nüfusu 495.688 kişi) ile oranlanmış, tüm müdürlüklere iletilen taleplerin nüfusa oranının \%1 ve üzerinde olduğu birimler değerlendirilmeye alınmış, talep sayısının çok az olduğu ve hesaplamalarda $\% 0$ olarak bulunan müdürlükler değerlendirme dışı bırakılmıştır. Bununla birlikte sıralamada onuncu sırada yer alan 'dış yönlendirmeler' 6 başlı̆̆ 1 da çalışma konusu dışında bırakılmıştır.

\footnotetext{
${ }^{6}$ Belediyeye gelen taleplerden, belediyenin görev ve hizmet kapsamı dışında kalanlarının, ilgili kurum ve kuruluşlara yönlendirilmesi konusunu kapsayan başlık.
} 
Bu haliyle ilk dokuz birime gelen talepler tüm taleplerin \%90'ını oluşturmuştur.

\section{Muratpaşa Belediyesi'nde Sosyo-Ekonomik Gelişmişlik Düzeylerine Göre Hizmet Talepleri}

Vatandaşlardan belediyeye gelen talepler belediye görevlileri tarafindan içeriklerine göre değerlendirilip aşağıdaki tabloda görülen ilgili 35 hizmet birimine yönlendirilmiştir. Belediyenin tüm birimlerine gelen toplam talep sayısı 119.427 'dir. Birimlere gelen hizmet talep sayıları ve yüzdesi tabloda gösterilmiştir. Buna göre, en fazla talebin Temizlik İşleri Müdürlüğü'ne (21549 talep), en az taleplerin ise Gecekondu ve Sosyal Konutlar Müdürlüğü ve Teftiş Kurulu Müdürlüğü'ne (1er talep) gittiği görülmektedir (Tablo 1).

Tablo 1. Hizmet Birimlerine Göre Talepler

\begin{tabular}{|c|c|c|}
\hline Hizmet Birimi & Kayıt Sayısı & $\%$ \\
\hline Temizlik İşleri Müdürlüğü & 21.549 & 18 \\
\hline Sosyal Yardım İşleri Müdürlüğ̈̈ü & 18.083 & 15 \\
\hline Çevre Koruma Ve Kontrol Müdürlüğü & 17.410 & 15 \\
\hline Zabita Müdürlüğ̈̈ & 13.007 & 11 \\
\hline Fen İşleri Müdürlüğü & 11.627 & 10 \\
\hline Park Ve Bahçeler Müdürlüğü & 10.061 & 8 \\
\hline Veteriner İşleri Müdürlüğü & 7.324 & 6 \\
\hline Sosyal Destek Hizmetleri Müdürlüğü & 5.713 & 5 \\
\hline Spor İşleri Müdürlüğ̈̈u & 3.264 & 3 \\
\hline Diş Yönlendirmeler & 2.209 & 2 \\
\hline Kreş Müdürlüğü & 1.440 & 1 \\
\hline Kadın ve Aile Hizmetleri Müdürlüğü & 1.022 & 1 \\
\hline Yap1 Kontrol Müdürlüğ̈̈ & 1.012 & 1 \\
\hline Halkla İlişkiler Müdürlüğü & 933 & 1 \\
\hline İmar Ve Şehircilik Müdürlüğü & 678 & 1 \\
\hline Turunç Masa & 592 & 0 \\
\hline Ruhsat Ve Denetim Müdürlüğü & 505 & 0 \\
\hline Emlak Ve İstimlak Müdürlüğü & 422 & 0 \\
\hline Özel Kalem Müdürlüğü & 365 & 0 \\
\hline İşletme Ve İştirakler Müdürlüğü & 339 & 0 \\
\hline Basın Ve Yayın Müdürlüğü & 308 & 0 \\
\hline Kültür Ve Sosyal İşler Müdürlüğü & 301 & 0 \\
\hline Mali Hizmetler Müdürlüğü & 261 & 0 \\
\hline Plan Ve Proje Müdürlüğü & 186 & 0 \\
\hline Sağlık İşleri Müdürlüğü & 186 & 0 \\
\hline Kütüphane Müdürlüğü & 161 & 0 \\
\hline İnsan Kaynakları Ve Eğitim Müdürlüğü & 154 & 0 \\
\hline Destek Hizmetleri Müdürlüğü & 144 & 0 \\
\hline Kentsel Tasarım Müdürlüğü & 91 & 0 \\
\hline
\end{tabular}




\begin{tabular}{lll}
\hline Bilgi İşlem Müdürlüğü & 41 & 0 \\
\hline Etüt Proje Müdürlüğü & 19 & 0 \\
\hline Yazi İşleri Müdürlüğü & 10 & 0 \\
\hline Hukuk İşleri Müdürlüğ̈u & 8 & 0 \\
\hline Gecekondu Ve Sosyal Konutlar Müdürlüğü & 1 & 0 \\
\hline Teftiş Kurulu Müdürlüğ̈ü & 1 & 0 \\
\hline Toplam & 119.427 & 100 \\
\hline
\end{tabular}

Kaynak: Muratpaşa Belediyesi verileri kullanılarak yazarlar tarafından oluşturulmuştur.

Birimler ve görev tanımlarına göre belediyenin yapmış olduğu sınıflandırma incelendiğinde, en fazla talebin geldiği ilk 9 birim Tablo 2'de yer almaktadır. Yöntem kısmında da açıklandığı gibi bu gruplandırma, tüm müdürlüklere iletilen taleplerin nüfusa oranının \%1 ve üzerinde olduğu birimler değerlendirmeye alınarak yapılmıştır. Bu haliyle en fazla talebin gittiği ilk 9 birime giden toplam talep sayısı 108.038'tür ve tüm birimlere giden toplam taleplerin (119.427) \%90'ını oluşturmuştur.

Tablo 2. Toplam talep sayılarına göre en çok talepte bulunulan 9 birim

\begin{tabular}{ll}
\hline Birim adı & Talep Sayısı \\
\hline Temizlik İşleri Müdürlüğü & 21.549 \\
\hline Sosyal Yardım İşleri Müdürlüğü & 18.083 \\
\hline Çevre Koruma Ve Kontrol Müdürlü̆g̈ü & 17.410 \\
\hline Zabıta Müdürlüğü & 13.007 \\
\hline Fen İşleri Müdürlüğü & 11.627 \\
\hline Park Ve Bahçeler Müdürlüğü & 10.061 \\
\hline Veteriner İşleri Müdürlüğü & 7.324 \\
\hline Sosyal Destek Hizmetleri Müdürlüğü & 5.713 \\
\hline Spor İşleri Müdürlüğü & 3.264 \\
\hline Toplam & 108.038
\end{tabular}

Kaynak: Muratpaşa Belediyesi verileri kullanılarak yazarlar tarafından oluşturulmuştur.

Belediye'ye gelen toplam taleplerin sosyo-ekonomik gelişmişlik düzeyine göre dağglımı şu şekildedir: A grubu \%31, B Grubu \%25, C Grubu \%25 ve D Grubu \%19. Buna göre, sosyo-ekonomik gelişmişlik seviyesi arttıkça genel olarak belediye ile iletişime geçme ve belediyeden hizmet talebinde bulunma eğilimi artış göstermektedir (Tablo 3). 
Tablo 3. Muratpaşa Belediyesi'nde Sosyo-Ekonomik Gelişmişlik Düzeylerine Göre Hizmet Talepleri

\begin{tabular}{lll}
\hline $\begin{array}{l}\text { Sosyo-Ekonomik } \\
\text { Gelişmişlik Düzeyi }\end{array}$ & Hizmet Talep Sayısı & Hizmet Talep Yüzdesi (\%) \\
\hline A & 36.452 & 31 \\
\hline B & 30.298 & 25 \\
\hline C & 30.060 & 25 \\
\hline D & 22.617 & 19 \\
\hline Toplam & 119.427 & 100 \\
\hline
\end{tabular}

Kaynak: Muratpaşa Belediyesi verileri kullanılarak yazarlar tarafından oluşturulmuştur.

\section{Sosyo-ekonomik Gelişmişlik Durumuna Göre Belediyeden Talep Edilen Hizmetlerin İçeriği}

En çok talebin geldiği ilk dokuz birim incelenirken, bunlara yöneltilen taleplerin içeriğine odaklanılmıştır. Bu çerçevede takip eden kısımda, birimler ve görev tanımları değil taleplerin içerikleri öncelikli olduğundan, içeriklere göre yeni bir sınıflandırma yapılmış, birim isimleri sınıflandırma dışı bırakılmıştır. Bu yaklaşımla, benzer içeriklerin farklı birimlerin altında tanımlanmış olduğu durumlarda ilgili veriler ortak bir başlıkta toplanmış, buna karşın tanımlanamamış (diğer ve personel ile ilgili veriler gibi) veriler değerlendirme dışı bırakılmıştır. Çalışma kapsamında oluşturulan yeni içerik başlıkları Tablo 4'te verilmiştir.

Yapılan sınıflandırmada doğal yapı/peyzaj işleri ile ilişkili olan hizmetler ve bu hizmetlere ilişkin talepler ile kent mobilyaları talep, bakım ve onarımına ilişkin başvurular "Açık ve Yeşil alan düzenleme, bakım ve temizlik" başlığı altında değerlendirilmiştir. Çocuk ve yetişkin spor talepleri, spor sahaları/aletleri talep bakım ve onarımı konuları ise "Sporla ilgili talepler" başlığ 1 altında incelenmiştir. Çevre kirliliği ve moloz ve hafriyat atıklarına ilişkin talepler "Çevre Kirliliği" başlığı altında birleştirilmiş, bununla birlikte Çevreci Komşu Kart, çöp konteyneri ile toplanan atıklar, geri dönüşüm talepleri, cadde-sokak temizliği, ev eşyası toplama ve çöp ev konuları içeriklerinin özellikleri göz önünde bulundurularak ayrı başlıklar altında ele alınmıştır.

Bu çerçevede, belediyeye yöneltilen hizmet taleplerinin genel olarak içeriğine bakıldığında, en çok talebi alan iki konunun açık ve yeşil alan düzenleme, bakım ve temizliği (\%13) ve Çevreci Komşu Kart (\%11) ile ilgili talepler olduğu görülmektedir (Tablo 4). En az talebin geldiği konu başlıkları ise sırasıyla çöp ev, gıda ve hijyen, yangın ve huzurevi/yaşlı evi olarak belirlenmiştir. 
Tablo 4. Sosyo-ekonomik gelişmişlik durumlarına göre talep içerikleri

\begin{tabular}{lllllll}
\hline \multicolumn{7}{l}{ Sosyo-ekonomik gelişmişlik } \\
\hline Talep içerikleri & A & B & C & D & Toplam & \% \\
\hline Açık ve yeşil alan düzenleme, bakım ve temizlik & 4.990 & 3.120 & 2.820 & 1.730 & 12.660 & 13 \\
\hline Çevreci Komşu Kart & 2.582 & 2.585 & 3.044 & 2.440 & 10.651 & 11 \\
\hline Evde sosyal hizmet, bakım ve hasta nakil & 2.630 & 2.142 & 2.067 & 1.536 & 8.375 & 9 \\
\hline Yardım hizmetleri (Ayni ve nakdi birlikte) & 1.866 & 2.422 & 2.114 & 1.909 & 8.311 & 9 \\
\hline Sokak hayvanları ve veteriner işleri & 2.747 & 2.365 & 1.625 & 1.131 & 7.868 & 8 \\
\hline Çöp konteyneri ile toplanan atıklar ve ilgili işler & 2.172 & 2.003 & 1.745 & 1.765 & 7.685 & 8 \\
\hline Ruhsat ve izin işlemleri & 2.043 & 1.908 & 2.037 & 865 & 6.853 & 7 \\
\hline Yol ve Asfalt talepleri & 1.517 & 1.192 & 1.803 & 1.641 & 6.153 & 6 \\
\hline Cenaze işleri & 1.333 & 1.273 & 1.552 & 1.491 & 5.649 & 6 \\
\hline Geri dönüşüm talepleri & 1.507 & 1.107 & 844 & 547 & 4.005 & 4 \\
\hline Cadde sokak temizliği & 1.023 & 826 & 1.084 & 827 & 3.760 & 4 \\
\hline Ev eşyası toplama & 1.311 & 881 & 901 & 634 & 3.727 & 4 \\
\hline Sporla ilgili talepler & 1.374 & 445 & 703 & 522 & 3.044 & 3 \\
\hline Sosyo kültürel yapı tadilatları ve temizliği & 652 & 606 & 660 & 578 & 2.496 & 3 \\
\hline Kaldırım talepleri & 688 & 514 & 573 & 629 & 2.404 & 2 \\
\hline Çevre Kirliliği & 347 & 410 & 378 & 283 & 1.418 & 1 \\
\hline Sosyo -kültürel hizmet ve eğitim talepleri & 302 & 194 & 216 & 142 & 854 & 1 \\
\hline Çöp ev & 47 & 48 & 39 & 19 & 153 & 0 \\
\hline Gıda ve hijyen & 34 & 46 & 32 & 25 & 137 & 0 \\
\hline Yangın & 10 & 37 & 26 & 33 & 106 & 0 \\
\hline Huzurevi ve yaşlı evi & 49 & 32 & 10 & 3 & 94 & 0 \\
\hline Toplam & & & & & 96.403 & 100 \\
\hline Kaynak: Mur & & & & & \\
\hline
\end{tabular}

Kaynak: Muratpaşa Belediyesi verileri kullanılarak yazarlar tarafından oluşturulmuştur.

Talep içerikleri sosyo-ekonomik gelişmişlik gruplarına göre incelenmiş ve her gruptan gelen talepler kendi içerisinde yüzdelik dilime göre sıralanmıştır (Tablo 5). Yapılan değerlendirmelerde ilk beş konu başlığı ele alınmış; bunun yanında sosyo-ekonomik gelişmişlik açısından önem arz eden farklılaşmalara da değinilmiştir.

A grubunda yer alan mahallelerden gelen taleplerin içeriği incelendiğinde, açık ve yeşil alanlarla ilgili taleplerin \%17 ile ilk sırada yer aldığı görülmektedir. Bunu \% 9 ile sokak hayvanları ve veteriner işleri, evde sosyal hizmet, bakım ve hasta nakil ile ilgili talepler ve Çevreci Komşu Kart (ÇKK) ile ilgili talepler takip etmektedir. Bu sıralamada ilk göze çarpan husus, klasik belediye hizmetleri arasında değerlendirilebilecek açı ve yeşil alan ile ilgili hizmetlerin yanında sokak hayvanları, evde sosyal hizmet ve çevreci komşu kart taleplerinin ön çıkıyor olmasıdır. 
$B$ grubundan gelen talepler incelendiğinde ise sırasıyla açık ve yeşil alanlarla ilgili talepler (\%13), ÇKK talepleri, yardım talepleri (ayni ve nakdi), sokak hayvanları/ veteriner işleri ile ilgili talepler ile evde sosyal hizmet, bakım ve hasta nakil ile ilgili taleplerin öne çıktığı görülmektedir.

C grubuna bakıldığında, ÇKK ile ilgili talepler (\% 13), açık ve yeşil alanlarla ilgili talepler, yardım talepleri, evde sosyal hizmet, bakım ve hasta nakil ile ilgili talepler ve ruhsat ve izin işlemleri öncelik açısından ilk beş konuyu oluşturmaktadır.

D grubunda ise ÇKK talepleri (\%13), yardım talepleri, çöp konteyneri ile toplanan atıklarla ilgili talepler, açık ve yeşil alanlarla ilgili talepler ve yol ve asfalt talepleri öne çımaktadır.

Tüm talep içerikleri genel olarak değerlendirildiğinde, açık ve yeşil alan ile ilgili talepler A ve B grubunda ilk sırada yer alırken, $C$ ve $D$ grubunda bu konuyla ilgili taleplerin ikinci ve dördüncü sıralarda yer aldığı görülmektedir. Buna karşılık C ve D grubunda ilk sırada yer alan Çevreci Komşu Kart ile ilgili talepler, A grubunda dördüncü, B grubunda ise ikinci sıraya düşmektedir. Zaman içerisinde diğer belediyelerdeki benzer uygulamalara örnek olan "Çevreci Komşu Kart Projesi" (ÇKK) ilk olarak Muratpaşa Belediyesi tarafından ambalaj atıklarının toplanması şeklinde hayata geçirilmiştir. Proje, sonrasında belediye tarafından diğer atıkların da (elektronik atık, bitkisel atık yağlar vb.) toplanmasını içerecek şekilde genişletilmiştir. Uygulamanın temelinde, vatandaşların belediyeye ilettikleri atıklar karşılığında elde ettikleri puanları market, sinema vb. yerlerde harcamaları veya bu puanları başarılı öğrencilere burs olarak aktarmaları yer almaktadır (Muratpaşa Belediyesi web sitesi, 2020). Bu haliyle değerlendirildiğinde ÇKK'nın ciddi bir ekonomik yönü olduğu görülmektedir. Dolayısıyla ÇKK'ya ilişkin taleplerin C ve D bölgelerinde ilk sırada yer alması şaşırtıcı olmamalıdır. Buna karşın sosyo-ekonomik gelişmişlik düzeyleri daha yüksek olan A ve B gruplarında bir geri dönüşüm projesi olarak da adlandırılabilecek ÇKK'nın ilk sıralarda yer almaması dikkat çekicidir. Bununla birlikte, bu çalışmada ayrı bir başlık olarak incelenen "Geri dönüşüm" ile ilgili taleplerin A ve B grubunda diğer iki gruba oranla daha öncelikli olduğu görülmektedir. Bu da ÇKK'ya ilişkin taleplerde dönüşüm kaygısından çok ekonomik getiri yönünün ön plana çıtığı şeklinde yorumlanabilir.

Dikkat çeken bir diğer konu da belediyeye iletilen sokak hayvanları ve veteriner işleri ile ilgili taleplerin A grubunda ikinci sırada yer alırken, B grubunda dördüncü sıraya, $C$ ve $D$ grubunda ise sekizinci sıraya düşüyor olma- 
sıdır. Bu durum, sosyo-ekonomik gelişmişlik düzeyi azaldıkça artan diğer ihtiyaçlarla birlikte öncelik sırasının değiştiğinin bir göstergesi olarak değerlendirilebilir.

Belediyelerin sundukları hizmetler arasında giderek önemi artan evde sosyal hizmet, bakım ve hasta nakil hizmetleri ile ilgili taleplerin A grubunda üçüncü sırada yer alırken, D grubunda altıncı sıraya gerilemesi dikkat çekicidir. Bu durum A grubunda hanehalkı sayısının görece daha az ve bu ailelerde çalışan kişi sayılarının daha fazla olduğunu, bunun yanında, sosyo-ekonomik gelişmişlik seviyesi azaldıkça geleneksel aile yapısının daha fazla korunduğu ve bu ailelerin söz konusu hizmetleri kendi içlerinde sağlamaya çalıştıklarını akla getirmektedir.

Belediyeye iletilmiş olan ayni ve nakdi yardım talepleri, A grubunda ilk beş talep konusu arasında yer almazken, B ve C grubunda üçüncü sırada yer almakta, D grubunda ise ikinci sıraya çıkmaktadır. Sosyo-ekonomik gelişmişlik düzeyi azaldıkça bu taleplerin artıyor olması beklenen bir durumdur.

Klasik belediye hizmetleri arasında sayılan çöp konteyneri ile toplanan atıklara ve yol ve asfalta ilişkin kentsel altyapı konularına dair taleplerin, sosyo-ekonomik gelişmişlik seviyesinin azaldığı bölgelerde, diğer bölgelere oranla daha ön sıralarda yer aldığı görülmektedir.

Yaşam koşullarının değişmesiyle birlikte belediyeden talep edilen hizmetlerin çeşitlenmesine örnek olarak gösterilebilecek diğer konular arasında vatandaşların belediyeye ilettikleri sporla ilgili talepler (spor sahaları/aletleri/tesisleri talep/bakım/onarımı ile çocuk ve yetişkin spor kursları talepleri) ile ev eşyası toplama (kullanılmayan elektrikli eşyalar, mobilyalar vb.) gibi konular da sayılabilir.

Belediyeden talep edilen hizmetler arasında yer alan huzurevi ve yaşlı evi, çöp ev, gida ve hijyen ve yangin konularındaki talepler sosyo-ekonomik gelişmişlik seviyelerinden bağımsız olarak her dört grup için de son dört sırada $(\sim 0)$ yer almaktadır.

Belediyeye iletilmiş olan talepler incelendiğinde, değişen güncel ihtiyaçlar ve artan bilinç seviyesi neticesinde, belediyeden talep edilen hizmetlerin çeşitlendiği ve sıralamanın buna göre şekillendiği görülmektedir. Bu kapsamda yeşil alan düzenleme/bakım/onarımı, çevreci komşu kart, evde bakım hizmetleri, hasta nakil ve sokak hayvanları ile ilgili taleplerin belirgin bir biçimde talep sıralamasında öne çıktığı gözlenmektedir. 
Tablo 5. Sosyo ekonomik gelişmişlik durumlarına göre talep edilen hizmetlerdeki değişim

\begin{tabular}{|c|c|c|c|c|c|c|c|c|}
\hline \multirow{2}{*}{$\begin{array}{l}\text { Öncelik } \\
\text { sırası }\end{array}$} & \multicolumn{8}{|c|}{ Sosyo ekonomik gelişmişlik gruplarına göre talep içerikleri } \\
\hline & A & $\%$ & B & $\%$ & C & $\%$ & D & $\%$ \\
\hline 1. & $\begin{array}{l}\text { Açı ve ye- } \\
\text { şil alan dü- } \\
\text { zenleme, } \\
\text { bakım ve te- } \\
\text { mizlik }\end{array}$ & 17 & $\begin{array}{l}\text { Açık ve yeşil } \\
\text { alan düzen- } \\
\text { leme, bakım ve } \\
\text { temizlik }\end{array}$ & 13 & $\begin{array}{l}\text { Çevreci } \\
\text { Komşu Kart }\end{array}$ & 13 & $\begin{array}{l}\text { Çevreci } \\
\text { Komşu Kart }\end{array}$ & 13 \\
\hline 2. & $\begin{array}{l}\text { Sokak hay- } \\
\text { vanları ve } \\
\text { veteriner iş- } \\
\text { leri }\end{array}$ & 9 & $\begin{array}{l}\text { Çevreci Komşu } \\
\text { Kart }\end{array}$ & 11 & $\begin{array}{l}\text { Açık ve yeşil } \\
\text { alan düzen- } \\
\text { leme, bakım ve } \\
\text { temizlik }\end{array}$ & 12 & $\begin{array}{l}\text { Yardım hiz- } \\
\text { metleri (Ayni } \\
\text { ve nakdi bir- } \\
\text { likte) }\end{array}$ & 10 \\
\hline 3. & $\begin{array}{l}\text { Evde sosyal } \\
\text { hizmet, ba- } \\
\text { kim ve } \\
\text { hasta nakil }\end{array}$ & 9 & $\begin{array}{l}\text { Yardım hiz- } \\
\text { metleri (Ayni } \\
\text { ve nakdi bir- } \\
\text { likte) }\end{array}$ & 10 & $\begin{array}{l}\text { Yardım hiz- } \\
\text { metleri (Ayni } \\
\text { ve nakdi bir- } \\
\text { likte) }\end{array}$ & 9 & $\begin{array}{l}\text { Çöp konteynırı } \\
\text { ile toplanan } \\
\text { atıklar ve ilgili } \\
\text { işler }\end{array}$ & 9 \\
\hline 4. & $\begin{array}{l}\text { Çevreci } \\
\text { Komşu Kart }\end{array}$ & 9 & $\begin{array}{l}\text { Sokak hayvan- } \\
\text { ları ve veteri- } \\
\text { ner işleri }\end{array}$ & 10 & $\begin{array}{l}\text { Evde sosyal } \\
\text { hizmet, bakım } \\
\text { ve hasta nakil }\end{array}$ & 9 & $\begin{array}{l}\text { Açı ve yeşil } \\
\text { alan düzen- } \\
\text { leme, bakım ve } \\
\text { temizlik }\end{array}$ & 9 \\
\hline 5. & $\begin{array}{l}\text { Çöp kontey- } \\
\text { nırı ile top- } \\
\text { lanan atıklar } \\
\text { ve ilgili işler }\end{array}$ & 7 & $\begin{array}{l}\text { Evde sosyal } \\
\text { hizmet, bakım } \\
\text { ve hasta nakil }\end{array}$ & 9 & $\begin{array}{l}\text { Ruhsat ve izin } \\
\text { işlemleri }\end{array}$ & 8 & $\begin{array}{l}\text { Yol ve Asfalt } \\
\text { talepleri }\end{array}$ & 9 \\
\hline 6. & $\begin{array}{l}\text { Ruhsat ve } \\
\text { izin işlem- } \\
\text { leri }\end{array}$ & 7 & $\begin{array}{l}\text { Çöp konteynırı } \\
\text { ile toplanan } \\
\text { atıklar ve ilgili } \\
\text { işler }\end{array}$ & 8 & $\begin{array}{l}\text { Yol ve Asfalt } \\
\text { talepleri }\end{array}$ & 7 & $\begin{array}{l}\text { Evde sosyal } \\
\text { hizmet, bakım } \\
\text { ve hasta nakil }\end{array}$ & 8 \\
\hline 7. & $\begin{array}{l}\text { Yardım hiz- } \\
\text { metleri } \\
\text { (Ayni ve } \\
\text { nakdi bir- } \\
\text { likte) }\end{array}$ & 6 & $\begin{array}{l}\text { Ruhsat ve izin } \\
\text { işlemleri }\end{array}$ & 8 & $\begin{array}{l}\text { Çöp konteynırı } \\
\text { ile toplanan } \\
\text { atıklar ve ilgili } \\
\text { işler }\end{array}$ & 7 & Cenaze işleri & 8 \\
\hline 8. & $\begin{array}{l}\text { Yol ve As- } \\
\text { falt talepleri }\end{array}$ & 5 & Cenaze işleri & 5 & $\begin{array}{l}\text { Sokak hayvan- } \\
\text { ları ve veteri- } \\
\text { ner işleri }\end{array}$ & 7 & $\begin{array}{l}\text { Sokak hayvan- } \\
\text { ları ve veteri- } \\
\text { ner işleri }\end{array}$ & 6 \\
\hline 9. & $\begin{array}{l}\text { Geri dönü- } \\
\text { şüm talep- } \\
\text { leri }\end{array}$ & 5 & $\begin{array}{l}\text { Yol ve Asfalt } \\
\text { talepleri }\end{array}$ & 5 & Cenaze işleri & 6 & $\begin{array}{l}\text { Ruhsat ve izin } \\
\text { işlemleri }\end{array}$ & 5 \\
\hline 10. & $\begin{array}{l}\text { Sporla ilgili } \\
\text { talepler }\end{array}$ & 5 & $\begin{array}{l}\text { Geri dönüşüm } \\
\text { talepleri }\end{array}$ & 5 & $\begin{array}{l}\text { Cadde sokak } \\
\text { temizliği }\end{array}$ & 4 & $\begin{array}{l}\text { Cadde sokak } \\
\text { temizliği }\end{array}$ & 4 \\
\hline 11. & $\begin{array}{l}\text { Cenaze iş- } \\
\text { leri }\end{array}$ & 5 & $\begin{array}{l}\text { Ev eşyası top- } \\
\text { lama }\end{array}$ & 4 & $\begin{array}{l}\text { Ev eşyası top- } \\
\text { lama }\end{array}$ & 4 & $\begin{array}{l}\text { Ev eşyası top- } \\
\text { lama }\end{array}$ & 3 \\
\hline 12. & $\begin{array}{l}\text { Ev eşyası } \\
\text { toplama }\end{array}$ & 4 & $\begin{array}{l}\text { Cadde sokak } \\
\text { temizliği }\end{array}$ & 3 & $\begin{array}{l}\text { Geri dönüşüm } \\
\text { talepleri }\end{array}$ & 3 & $\begin{array}{l}\text { Kaldırım talep- } \\
\text { leri }\end{array}$ & 3 \\
\hline 13. & $\begin{array}{l}\text { Cadde so- } \\
\text { kak temiz- } \\
\text { liği }\end{array}$ & 4 & $\begin{array}{l}\text { Sosyo kültürel } \\
\text { yapı tadilatları } \\
\text { ve temizliği }\end{array}$ & 3 & $\begin{array}{l}\text { Sporla ilgili ta- } \\
\text { lepler }\end{array}$ & 3 & $\begin{array}{l}\text { Sosyo kültürel } \\
\text { yapı tadilatları } \\
\text { ve temizliği }\end{array}$ & 3 \\
\hline 14. & $\begin{array}{l}\text { Kaldırım ta- } \\
\text { lepleri }\end{array}$ & 2 & $\begin{array}{l}\text { Kaldırım talep- } \\
\text { leri }\end{array}$ & 2 & $\begin{array}{l}\text { Sosyo kültürel } \\
\text { yapı tadilatları } \\
\text { ve temizliği }\end{array}$ & 3 & $\begin{array}{l}\text { Geri dönüşüm } \\
\text { talepleri }\end{array}$ & 3 \\
\hline
\end{tabular}




\begin{tabular}{|c|c|c|c|c|c|c|c|c|}
\hline 15. & $\begin{array}{l}\text { Sosyo kül- } \\
\text { türel yapı } \\
\text { tadilatları } \\
\text { ve temizliği }\end{array}$ & 2 & $\begin{array}{l}\text { Sporla ilgili ta- } \\
\text { lepler }\end{array}$ & 2 & $\begin{array}{l}\text { Kaldırım talep- } \\
\text { leri }\end{array}$ & 2 & $\begin{array}{l}\text { Sporla ilgili ta- } \\
\text { lepler }\end{array}$ & 3 \\
\hline 16. & $\begin{array}{l}\text { Çevre Kirli- } \\
\text { liği }\end{array}$ & 1 & Çevre Kirliliği & 2 & Çevre Kirliliği & 2 & Çevre Kirliliği & 2 \\
\hline 17. & $\begin{array}{l}\text { Sosyo -kül- } \\
\text { türel hizmet } \\
\text { ve eğitim ta- } \\
\text { lepleri }\end{array}$ & 1 & $\begin{array}{l}\text { Sosyo -kültürel } \\
\text { hizmet ve eği- } \\
\text { tim talepleri }\end{array}$ & 1 & $\begin{array}{l}\text { Sosyo -kültürel } \\
\text { hizmet ve eği- } \\
\text { tim talepleri }\end{array}$ & 1 & $\begin{array}{l}\text { Sosyo -kültürel } \\
\text { hizmet ve eği- } \\
\text { tim talepleri }\end{array}$ & 1 \\
\hline 18. & $\begin{array}{l}\text { Huzurevi } \\
\text { ve yaşlı evi }\end{array}$ & 0 & Çöp ev & 0 & Çöp ev & 0 & Yangin & 0 \\
\hline 19. & Çöp ev & 0 & Gida ve hijyen & 0 & Gida ve hijyen & 0 & Gida ve hijyen & 0 \\
\hline 20. & $\begin{array}{l}\text { Gida ve hij- } \\
\text { yen }\end{array}$ & 0 & Yangin & 0 & Yangin & 0 & Çöp ev & 0 \\
\hline 21. & Yangin & 0 & $\begin{array}{l}\text { Huzurevi ve } \\
\text { yaşlı evi }\end{array}$ & 0 & $\begin{array}{l}\text { Huzurevi ve } \\
\text { yaşli evi }\end{array}$ & 0 & $\begin{array}{l}\text { Huzurevi ve } \\
\text { yaşlı evi }\end{array}$ & 0 \\
\hline
\end{tabular}

Kaynak: Muratpaşa Belediyesi verileri kullanılarak yazarlar tarafından oluşturulmuştur.

\section{Sosyo-ekonomik Gelişmişlik Durumuna Göre Belediyeden Hizmet Talep Etme Yöntemleri}

Çalışmanın bu bölümünde vatandaşların belediyeye yönelttikleri taleplerinde hangi başvuru yöntemlerini tercih ettikleri incelenmiştir. Bu incelemede, Tablo 2'de belirtilen en fazla talebin geldiği ilk dokuz birime ait başvuru sayıları değerlendirmeye alınarak, başvuru yöntemleri sosyo-ekonomik gelişmişlik seviyelerine göre analiz edilmiştir (Tablo 6).

Elde edilen sonuçlara göre, geleneksel/yüz yüze iletişim yöntemlerinin online (internet tabanlı) iletişim yöntemlerine kıyasla açı ara önde olduğu (\%93) görülmüştür. Geleneksel iletişim yöntemleri olarak ele alınan çağrn merkezi \%84, başvuru masası \%6, gezici ekip $\% 2$, dilekçe $\% 1$ oranında tercih edilmiştir. Açık kapı ve özel kalem kanalıyla yapılan başvurular \%1'in altındadır. Online iletişim yöntemleri toplamda $\% 5$ oranında tercih edilmiş olup, tercihler e-posta/websitesi \%4, Belediyenin Facebook hesabı \%1, ve diğer tüm online kanallar (Belediye Başkanının Facebook hesabı, Belediyenin ve Belediye Başkanının Twitter hesapları, Belediyenin mobil uygulaması) birlikte $\% 1$ oranındadır. Cimer ve Bimer kanalları ile yapılan başvurular hem online hem de yüz yüze başvuru yöntemlerinden oluştuğu için iki gruba da dahil edilmemiştir. Online başvuru yöntemleri kendi içinde değerlendirildiğinde, belediyenin resmi e-posta adresi ve web sitesinin, belediyeye ve Belediye Başkanına ait sosyal medya hesaplarına kıyasla daha fazla tercih edildiği görülmektedir (Tablo 6). 
Tablo 6. Sosyo-ekonomik gelişmişlik düzeylerine göre başvuru biçimleri

\begin{tabular}{|c|c|c|c|c|c|}
\hline Başvuru biçimi & & Toplam & $\%$ & Toplam & $\%$ \\
\hline \multirow{4}{*}{ Çağrı Merkezi } & A & 26923 & 30 & & \\
\hline & $\mathrm{B}$ & 22578 & 25 & & \\
\hline & $\mathrm{C}$ & 23011 & 25 & & \\
\hline & $\mathrm{D}$ & 17790 & 20 & 90302 & 84 \\
\hline \multirow{4}{*}{ Başvuru Masası } & A & 2675 & 41 & & \\
\hline & $\mathrm{B}$ & 1583 & 24 & & \\
\hline & $\mathrm{C}$ & 1284 & 20 & & \\
\hline & $\mathrm{D}$ & 987 & 15 & 6529 & 6 \\
\hline \multirow{4}{*}{ E-Posta-Websitesi } & $\mathrm{A}$ & 1323 & 32 & & \\
\hline & $\mathrm{B}$ & 1082 & 26 & & \\
\hline & $\mathrm{C}$ & 985 & 24 & & \\
\hline & $\mathrm{D}$ & 759 & 18 & 4149 & 4 \\
\hline \multirow{4}{*}{ Gezici Ekip } & A & 539 & 21 & & \\
\hline & $\mathrm{B}$ & 553 & 21 & & \\
\hline & $\mathrm{C}$ & 1067 & 41 & & \\
\hline & $\mathrm{D}$ & 451 & 17 & 2610 & 2 \\
\hline \multirow{4}{*}{ Cimer } & $\mathrm{A}$ & 229 & 21 & & \\
\hline & $\mathrm{B}$ & 313 & 29 & & \\
\hline & $\mathrm{C}$ & 307 & 28 & & \\
\hline & $\mathrm{D}$ & 241 & 22 & 1090 & 1 \\
\hline \multirow{4}{*}{ Bimer } & A & 213 & 22 & & \\
\hline & $\mathrm{B}$ & 312 & 33 & & \\
\hline & $\mathrm{C}$ & 257 & 27 & & \\
\hline & $\mathrm{D}$ & 170 & 18 & 952 & 1 \\
\hline \multirow{4}{*}{ Facebook Belediye } & A & 253 & 33 & & \\
\hline & $\mathrm{B}$ & 186 & 24 & & \\
\hline & $\mathrm{C}$ & 161 & 21 & & \\
\hline & $\mathrm{D}$ & 171 & 22 & 771 & 1 \\
\hline \multirow{4}{*}{ Dilekçe } & A & 297 & 41 & & \\
\hline & $\mathrm{B}$ & 205 & 28 & & \\
\hline & $\mathrm{C}$ & 143 & 20 & & \\
\hline & $\mathrm{D}$ & 79 & 11 & 724 & 1 \\
\hline \multirow{4}{*}{ Facebook Başkan } & A & 144 & 28 & & \\
\hline & $\mathrm{B}$ & 144 & 28 & & \\
\hline & $\mathrm{C}$ & 124 & 24 & & \\
\hline & $\mathrm{D}$ & 95 & 19 & 507 & 0 \\
\hline \multirow{4}{*}{ Twitter Belediye } & A & 91 & 44 & & \\
\hline & $\mathrm{B}$ & 39 & 19 & & \\
\hline & $\mathrm{C}$ & 47 & 23 & & \\
\hline & $\mathrm{D}$ & 31 & 15 & 208 & 0 \\
\hline \multirow{4}{*}{ Mobil } & $\mathrm{A}$ & 20 & 24 & & \\
\hline & $\mathrm{B}$ & 24 & 29 & & \\
\hline & $\mathrm{C}$ & 26 & 32 & & \\
\hline & $\mathrm{D}$ & 12 & 15 & 82 & 0 \\
\hline \multirow{4}{*}{ Açık Kapı } & A & 8 & 14 & & \\
\hline & $\mathrm{B}$ & 24 & 41 & & \\
\hline & $\mathrm{C}$ & 15 & 26 & & \\
\hline & $\mathrm{D}$ & 11 & 19 & 58 & 0 \\
\hline
\end{tabular}


Tablo 6. (Devamı) Sosyo-ekonomik gelişmişlik düzeylerine göre başvuru biçimleri

\begin{tabular}{|c|c|c|c|c|c|}
\hline \multirow{4}{*}{ Özel Kalem } & $\mathrm{A}$ & 18 & 44 & \multirow[b]{4}{*}{41} & \multirow[b]{4}{*}{0} \\
\hline & $\mathrm{B}$ & 10 & 24 & & \\
\hline & $\mathrm{C}$ & 7 & 17 & & \\
\hline & $\mathrm{D}$ & 6 & 15 & & \\
\hline \multirow{4}{*}{ Twitter Başkan } & A & 3 & 23 & \multirow[b]{4}{*}{13} & \multirow[b]{4}{*}{0} \\
\hline & B & 6 & 46 & & \\
\hline & $\mathrm{C}$ & 2 & 15 & & \\
\hline & $\mathrm{D}$ & 2 & 15 & & \\
\hline Toplam & \multicolumn{3}{|c|}{108036} & \multicolumn{2}{|c|}{108036} \\
\hline
\end{tabular}

Kaynak: Muratpaşa Belediyesi verileri kullanılarak yazarlar tarafından oluşturulmuştur.

Sosyo-ekonomik gelişmişlik durumuna göre başvuru yöntemleri incelendiğinde dört bölgede de ilk iki sırada yüz yüze iletişim yöntemlerinin (çağrı merkezi ve başvuru masası; A grubu \%90, B grubu \%89, C grubu \%89, D grubu \%91) yer aldığı görülmektedir. Sosyo-ekonomik gelişmişlik düzeyi azaldıkça, çağrı merkezi kanalı ile yapılan başvuru sayısı artmakta, buna karşın başvuru masası daha az tercih edilmektedir. Sosyo-ekonomik gelişmişlik seviyesinin online başvuru yöntemlerini kullanmada ayırıcı bir etkisi olduğu görülmemektedir. Tüm online başvuru yöntemleri her dört grupta aynı oranlarda tercih edilmektedir (A grubu \%5, B grubu \%6, C grubu \%5 ve D grubu \%5). Bu durum örneklem alan için dijital ayrışma olmadığg şeklinde yorumlanabilir (Tablo 7).

Tablo 7. Sosyo-ekonomik gelişmişlik düzeyine göre başvuru tercihlerindeki farklılaşma

\begin{tabular}{|c|c|c|c|c|c|c|c|c|c|c|c|}
\hline \multicolumn{3}{|l|}{ A Grubu } & \multicolumn{3}{|l|}{ B Grubu } & \multicolumn{3}{|l|}{ C Grubu } & \multicolumn{3}{|l|}{ D Grubu } \\
\hline Başvuru & & & Başvuru & & & Başvuru & & & Başvuru & & \\
\hline $\begin{array}{l}\text { Yön- } \\
\text { temi }\end{array}$ & Sayı & $\%$ & $\begin{array}{l}\text { Yön- } \\
\text { temi }\end{array}$ & Sayı & $\%$ & $\begin{array}{l}\text { Yön- } \\
\text { temi }\end{array}$ & Sayı & $\%$ & $\begin{array}{l}\text { Yön- } \\
\text { temi }\end{array}$ & Sayı & $\%$ \\
\hline $\begin{array}{l}\text { Çağrı } \\
\text { Merkezi }\end{array}$ & 26923 & 82 & $\begin{array}{l}\text { Çağrı } \\
\text { Merkezi }\end{array}$ & 22578 & 83 & $\begin{array}{l}\text { Çağrı } \\
\text { Merkezi }\end{array}$ & 23011 & 84 & $\begin{array}{l}\text { Çağrı } \\
\text { Merkezi }\end{array}$ & 17790 & 86 \\
\hline $\begin{array}{l}\text { Başvuru } \\
\text { Masası }\end{array}$ & 2675 & 8 & $\begin{array}{l}\text { Başvuru } \\
\text { Masası }\end{array}$ & 1583 & 6 & $\begin{array}{l}\text { Başvuru } \\
\text { Masası }\end{array}$ & 1284 & 5 & $\begin{array}{l}\text { Başvuru } \\
\text { Masası }\end{array}$ & 987 & 5 \\
\hline $\begin{array}{l}\text { E-Posta- } \\
\text { Websi- } \\
\text { tesi }\end{array}$ & 1323 & 4 & $\begin{array}{l}\text { E-Posta- } \\
\text { Websi- } \\
\text { tesi }\end{array}$ & 1082 & 4 & $\begin{array}{l}\text { Gezici } \\
\text { Ekip }\end{array}$ & 1067 & 4 & $\begin{array}{l}\text { E-Posta- } \\
\text { Websi- } \\
\text { tesi }\end{array}$ & 759 & 4 \\
\hline $\begin{array}{l}\text { Gezici } \\
\text { Ekip }\end{array}$ & 539 & 2 & $\begin{array}{l}\text { Gezici } \\
\text { Ekip }\end{array}$ & 553 & 2 & $\begin{array}{l}\text { E-Posta- } \\
\text { Websi- } \\
\text { tesi }\end{array}$ & 985 & 4 & $\begin{array}{l}\text { Gezici } \\
\text { Ekip }\end{array}$ & 451 & 2 \\
\hline Dilekçe & 297 & 1 & Cimer & 313 & 1 & Cimer & 307 & 1 & Cimer & 241 & 1 \\
\hline $\begin{array}{l}\text { Fa- } \\
\text { cebook } \\
\text { Belediye }\end{array}$ & 253 & 1 & Bimer & 312 & 1 & Bimer & 257 & 1 & $\begin{array}{l}\text { Fa- } \\
\text { cebook } \\
\text { Belediye }\end{array}$ & 171 & 1 \\
\hline
\end{tabular}




\begin{tabular}{|c|c|c|c|c|c|c|c|c|c|c|c|}
\hline Cimer & 229 & 1 & Dilekçe & 205 & 1 & $\begin{array}{l}\text { Fa- } \\
\text { cebook } \\
\text { Belediye }\end{array}$ & 161 & 1 & Bimer & 170 & 1 \\
\hline Bimer & 213 & 1 & $\begin{array}{l}\text { Fa- } \\
\text { cebook } \\
\text { Belediye }\end{array}$ & 186 & 1 & Dilekçe & 143 & 0 & $\begin{array}{l}\text { Fa- } \\
\text { cebook } \\
\text { Başkan }\end{array}$ & 95 & 0 \\
\hline $\begin{array}{l}\text { Fa- } \\
\text { cebook } \\
\text { Başkan }\end{array}$ & 144 & 0 & $\begin{array}{l}\text { Fa- } \\
\text { cebook } \\
\text { Başkan }\end{array}$ & 144 & 1 & $\begin{array}{l}\text { Fa- } \\
\text { cebook } \\
\text { Başkan }\end{array}$ & 124 & 0 & Dilekçe & 79 & 0 \\
\hline $\begin{array}{l}\text { Twitter } \\
\text { Belediye }\end{array}$ & 91 & 0 & $\begin{array}{l}\text { Twitter } \\
\text { Belediye }\end{array}$ & 39 & 0 & $\begin{array}{l}\text { Twitter } \\
\text { Belediye }\end{array}$ & 47 & 0 & $\begin{array}{l}\text { Twitter } \\
\text { Belediye }\end{array}$ & 31 & 0 \\
\hline Mobil & 20 & 0 & $\begin{array}{l}\text { Açık } \\
\text { Kapı }\end{array}$ & 24 & 0 & Mobil & 26 & 0 & Mobil & 12 & 0 \\
\hline $\begin{array}{l}\text { Özel Ka- } \\
\text { lem }\end{array}$ & 18 & 0 & Mobil & 24 & 0 & $\begin{array}{l}\text { Açık } \\
\text { Kapı }\end{array}$ & 15 & 0 & $\begin{array}{l}\text { Açık } \\
\text { Kapı }\end{array}$ & 11 & 0 \\
\hline $\begin{array}{l}\text { Açık } \\
\text { Kapı }\end{array}$ & 8 & 0 & $\begin{array}{l}\text { Özel Ka- } \\
\text { lem }\end{array}$ & 10 & 0 & $\begin{array}{l}\text { Özel Ka- } \\
\text { lem }\end{array}$ & 7 & 0 & $\begin{array}{l}\text { Özel Ka- } \\
\text { lem }\end{array}$ & 6 & 0 \\
\hline $\begin{array}{l}\text { Twitter } \\
\text { Başkan }\end{array}$ & 3 & 0 & $\begin{array}{l}\text { Twitter } \\
\text { Başkan }\end{array}$ & 6 & 0 & $\begin{array}{l}\text { Twitter } \\
\text { Başkan }\end{array}$ & 2 & 0 & $\begin{array}{l}\text { Twitter } \\
\text { Başkan }\end{array}$ & 2 & 0 \\
\hline
\end{tabular}

Kaynak: Muratpaşa Belediyesi verileri kullanılarak yazarlar tarafından oluşturulmuştur.

\section{Tartışma ve Sonuç}

Çalışmadan elde edilen sonuçların, çalışmanın başında ortaya konulan "vatandaşların belediyeden talep etmiş oldukları hizmetlerin miktarının ve içeriğinin onların sosyo-ekonomik gelişmişlik düzeyleri ile yakından ilişkili olduğu hipotezini" doğrular nitelikte olduğu görülmektedir. Ayrıca çalışmanın bir diğer hipotezi gelişen bilgi ve iletişim teknolojilerinin ışığında, belediye-vatandaş ilişkilerinde internet tabanlı iletişim yöntemlerini kullanma tercihlerinde artış olacağıdır. Ancak araştırma sonuçlarında vatandaşların belediye ile iletişim kurma yöntemi olarak hala yüz yüze iletişim kanallarını tercih ettiği görülmektedir. Bu durumda ikinci hipotezin bu çalışma özelinde geçerli olmadığı söylenebilir.

İlk hipotezden yola çkıllarak, yapılan araştırma sonucunda; vatandaşların sosyo-ekonomik gelişmişlik seviyeleri arttıkça belediye ile iletişime geçme eğilimlerinin ve belediyeden talep etmiş oldukları hizmet sayısının arttığı görülmektedir. Belediyeye yapılan taleplerin içeriğine bakıldığında ise, yine sosyo-ekonomik gelişmişlik seviyelerinin bu taleplerin belirlenmesinde etkili olduğu söylenebilir. En çok talep edilen iki konunun açık ve yeşil alan düzenleme, bakım ve temizliği ve Çevreci Komşu Kart (ÇKK) ile ilgili talepler olduğu görülmektedir. ÇKK'ya ilişkin taleplerde dönüşüm kaygısından çok ekonomik getiri yönünün ön plana çıktığına dair izlenimler öne çıkmıştır. 
Taleplerin içeriğine dair bir diğer gözlem de sosyo-ekonomik gelişmişlik düzeyi azaldıkça artan diğer ihtiyaçlarla birlikte öncelik sırasının değiştiği yönünde olmuştur. Özellikle ayni ve nakdi yardım taleplerinin sosyo-ekonomik gelişmişlik düzeyi azaldıkça artıyor olması bu değişim için dikkat çekici bir içerik olarak izlenmektedir. Öte yandan klasik belediye hizmetleri arasında sayılan çöp konteyneri ile toplanan atıklara ve yol ve asfalta ilişkin kentsel altyapı konularına dair taleplerin, sosyo-ekonomik gelişmişlik seviyesinin azaldığı bölgelerde, diğer bölgelere oranla daha ön sıralarda yer aldığı da bir diğer bulgudur.

Sosyo-ekonomik gelişmişlik seviyesinin yanında, belediyeden talep edilen hizmetlerin içeriğinin, değişen yaşam koşulları ile birlikte çeşitlendiği de gözlenmektedir. Vatandaşların belediyeye ilettikleri sporla ilgili talepler (spor sahaları/aletleri/tesisleri talep/bakım/onarımı ile çocuk ve yetişkin spor kursları talepleri) ile ev eşyası toplama (kullanılmayan elektrikli eşyalar, mobilyalar vb.) gibi konular bu çerçevede sayılabilir.

Çalışmanın ikinci hipotezi değerlendirildiğinde ise, elde edilen sonuçlara göre vatandaşların belediyeden hizmet talep etme yöntemleri açısından, geleneksel/yüz yüze iletişim yöntemlerinin online (internet tabanlı) iletişim yöntemlerine göre açık ara önde olduğu görülmektedir. Bu durum çalışmanın bulgularının, literatürden takip edilen çalışmalarla uyumlu olduğuna işaret etmektedir. Yüz yüze iletişim yöntemleri arasında çağn merkezinin büyük farkla önde olduğu ve onu başvuru masasının izlediği tespit edilmiştir. Online başvuru yöntemleri içinde de belediyenin resmi e-posta adresi ve web sitesinin, belediyeye ve Belediye Başkanına ait sosyal medya hesaplarına oranla daha fazla tercih edildiği görülmektedir. Öte yandan, sosyo-ekonomik gelişmişlik durumunun başvuru yöntemleri üzerinde bir etkisinin olmadığı gözlenmektedir. Tüm sosyo-ekonomik gelişmişlik grupları için ilk iki sırada yüz yüze iletişim yöntemlerinin (çağrı merkezi ve başvuru masası) yer aldığı görülmektedir. Sosyo-ekonomik gelişmişlik düzeyi azaldıkça, çağrı merkezi kanalı ile yapılan başvuru sayısı artmakta, buna karşın başvuru masası daha az tercih edilmektedir. Buradan hareketle, örneklem alan için, sosyo-ekonomik gelişmişlik seviyesinin online başvuru yöntemlerini kullanmada ayırıcı bir etkisinin bulunmadığı ve dijital ayrışmanın etkisinin olmadığı kanaatine varılmaktadır.

Genel olarak değerlendirildiğinde, teknolojik ve sosyo-ekonomik alandaki değişimlerin belediye hizmetlerinin içeriğine ve çeşitliliğine önemli etkileri olduğu görülmektedir. Bu durum, belediyelerin sundukları hizmetleri, 
bunun için kurmuş oldukları yapılanmaları ve hizmet sunumundaki önceliklerini yeniden gözden geçirmeleri ve buna göre yaklaşımlar geliştirmeleri gerektiğine işaret etmektedir. Özellikle ayn belediye sınırları içerisinde yaşayan, farklı sosyo-ekonomik gelişmişlik seviyesine sahip vatandaşlar arasında gözlenen farklı hizmet taleplerinin dikkatlice değerlendirilip eşitsizliğe yol açmayacak şekilde gerekli adımların atılması önem arz etmektedir. Buradan bakıldığında, ülkemizde 1970'li yıllarda tartışılmaya ve uygulanmaya başlanmış olan sosyal belediyecilik anlayışının günümüz koşullarında yeniden değerlendirilip uygulama alanının geliştirilmesi bir seçenek olarak varlığını korumaktadır. Keza yine günümüzün sosyo-ekonomik ve teknolojik gelişmelerinin karmaşıklığı ile baş etmede yararlanılabilecek entegre/karma modeller geliştirilmesi de önemle üzerinde durulması gereken bir konu olarak öne çıkmaktadır. Yapılabilecek bir başka öneri de belediyelerin değişen koşullarda ortaya çıkan farklı hizmet taleplerine cevap verirken, kurulacak birimleri dikkatlice gözden geçirmeleri ve görev ve yetki karmaşasına sebep olmayacak şekilde gerekli birimlerin kurulmasına özen gösterilmesi olabilir.

Belediyelerin, vatandaşla olan iletişimlerini sağlarken, olabildiğince kapsayıc yöntemler geliştirmeleri, vatandaşların kendileriyle iletişim kurma tercihlerini dikkate alarak, teknolojik ve sosyo-ekonomik alanda yaşanan değişimlere cevap verebilecek uygulamaları hayata geçirmeleri önem arz etmektedir. Geleneksel ve online iletişim yöntemlerini bir arada sunan bütüncül bir yaklaşım bu değişimlere daha rahat uyum sağlanmasına katkıda bulunacaktir.

Sonuç olarak, belediyelerin toplumda yaşanan ekonomik, sosyal ve teknolojik değişimleri ve buna paralel gelişen/gelişebilecek hizmet taleplerini iyi okumaları ve buna göre politika belirlemeleri önerilmektedir. Belediyelerin kendi sınırları içerisindeki sosyo-ekonomik gelişmişlik farklılıklarını gidermeyi amaçlayan ve daha adil ve eşitlikçi hizmet sunumunu hedefleyen bir anlayış ile bu hizmetlere erişimi kolaylaştıracak iletişim yöntemlerini hayata geçirmek için çalışmalar yapmaları önem arz etmektedir. 


\section{Extended Abstract}

\section{The Relation Between Socio-Economic Development Level and Service Demand in Local Governments: The Case of Muratpasa Municipality of Antalya Province}

\author{
Nilüfer Gürer \\ ORCID: 0000-0001-5476-9382
}

\author{
Bengi Demirci \\ ORCID: 0000-0002-7515-4982
}

Socio-economic changes and their resulting outcomes such as unemployment, poverty, changes in demographic structure and life styles together with the developments in information and communication technologies have affected both the content of the services demanded from the local governments and their way of demand. In this respect, services traditionally provided by and demanded from the municipalities as being the most prominent local government unit have been changing. Moreover, it is seen that social municipalism practices continue to be on the agenda of municipalities vis a vis the aforementioned changes. In addition to these, it has been detected that municipalities are inclined to adopt internet-based communication methods to respond to the demands directed by the citizens.

In general municipal services involve the provision of urban planning, infrastructure, recycling, transportation, parks and green spaces, public health, education, cultural services, etc. which are common to local residents. As it can be traced from the findings of the research, it is seen that both the services demanded from the municipalities and the services actually provided by them have been changing as a result of socio-economic changes and technological developments. Therefore, various additions/removals from the typical municipal services have been observed together with more/less concentration in some service areas during certain periods in the face of these changes.

When the services provided by the municipalities in Turkey is analyzed, it is seen that a more or less similar pattern has been followed. From the early 
Republican era, services provided by the municipalities have been differentiated periodically due to the changes in socio-economic structure. It has been observed that globalization/decentralization dynamics, globally competing cities, changes in technological, demographic, socio-economic, political and cultural conditions highly affect municipal services. As a result of these effects, demands for energy, environmental protection, training for adults, specific social services (e.g. service demands for specific illnesses), employment, etc. have come to the fore among the changing demands from the municipalities.

The pace of information and communication technologies and their adaptation in daily lives have affected not only interpersonal communication but also the communication and interaction of the citizens with governmental institutions including their information exchange and service demand. Intense use of online platforms and particularly social media tools by different stakeholders recently have urged local governments to get their places in these platforms and to use these tools in their service delivery. A similar trend has also been followed by the municipalities in Turkey in terms of using online communication tools.

In this respect, the aim of this study is to understand how the relationship between the citizens and the municipalities are affected by the socio-economic and technological changes and to analyze whether the effect of these changes differ due to socio-economic development levels of the citizens in the same municipal area; and if it does, to understand what kind of a change it is.

This study has two main hypotheses. The first one is that there is a close relation between the socio-economic development levels of the citizens and the quantity and content of the services they demanded from the municipality. And the second one is that in the face of technological developments, particularly the ones in information and communication technologies, there would be an increase in the use of online communication methods in citizen-municipality relations.

In this research, service demands made by the residents from the Muratpasa Municipality and their way of expressing these demands are analyzed according to four different socio-economic development zones. Frequency distribution of the data on the content/type of the demands of the residents and of the data on the method they prefer to communicate these demands to the municipality are examined. Data used in the analysis were obtained from the Muratpasa Municipality. Muratpasa Municipality was chosen as the case of this research mainly because it has been trying to integrate recent digital methods with 
rather classical ordinary ones in its interaction with the residents. It is the second most populated municipality in Antalya.

The results driven from the research have verified the first hypothesis that there is a close relation between the socio-economic development levels of the citizens and the quantity and content of the services they demanded from the municipality. Findings from the research show that as socio-economic development level increases, citizens are more inclined to contact the municipality and the number of demands they make from the municipality also increase. It can also be said that socio-economic development level determines the content of the demands made by the citizens from the Municipality. Moreover, it is seen that although demands about environmental and social support issues are ranking high, it is obvious that demands resulting from the frequently encountered economic and social urban changes (such as becoming a consumption society, becoming ageing communities) including changes in lifestyles are passed onto the local governments. This can be observed in the increase in the demands for sports facilities, for the collection of unused electronic devices and furnitures, etc. It can be added that as socio-economic development level decreases, due to the emergence of other prior service needs, the ranking of demands changes.

When it comes to the second hypothesis that there would be an increase in the use of online communication methods in citizen-municipality relations, it has been found out that citizens do prefer face-to-face communication in their relations with the municipality. Therefore, it can be stated that this hypothesis has not been confirmed in this specific case. Among the face-to-face communication methods, which have been by far the most preferred contact methods compared to the online (internet-based) ones, call center has been the most preferred channel which has been followed by the information desk. However, it has been observed that socio-economic development level does not have a significant impact on the communication method preferences of the citizens. For all socio-economic development groups, face-to-face communication methods (call center and information desk) are the most preferred ones. This implies that socio-economic development level does not have a differentiating effect on the use of online methods and that digital divide does not have a significant impact in this case.

To conclude, it is recommended that local governments follow economic, social and technological changes that have been taking place in the society and to detect emerging service demands as a result of these changes and thus formulate and implement policies accordingly. In so doing, it is important that 
local governments adopt a perspective which aims at eliminating inequalities with respect to socio-economic development levels within their boundaries and to provide equal and fair urban services to their residents and to devise proper communication channels which would make it easier for them to access these services.

\section{Kaynakça/References}

Aji, G. G., Suroyya ve T., ve Dewi, P. A. R. (2018). Bridging communication between public and government: a case study on kim surabaya. The 2nd International Joint Conference on Science and Technology (IJCST) 2017, Journal of Physics: Conf. Series 953, 16. doi : 10.1088/1742-6596/953/1/012194.

Avrupa Yerel Yönetimler Özerklik Şartı. (1992, 3 Ekim). Resmi Gazete (Sayı: 21364). https://www.resmigazete.gov.tr/arsiv/21364.pdf adresinden erişilmiştir.

Belediye Kanunu (2005, 13 Temmuz). Resmi Gazete (25874) https://www.mevzuat.gov.tr/MevzuatMetin/1.5.5393.pdf adresinden erişilmiştir.

Cohen, J. (2006). Citizen satisfaction with contacting government on the internet. Information Polity, 11(1), 51-65

Ebbers, W.E., Pieterson, W.J. ve Noordman, H.N. (2008). Electronic government: Rethinking channel management strategies. Government Information Quarterly, 25(2), 181201.

Government of the Netherlands. Municipalities' tasks. 14.01.2020 tarihinde https://www.government.nl/topics/municipalities/municipalities-tasks adresinden erişildi.

Gözler, K. (2018). Türkiye'nin yönetim yapısı (T. C. İdari Teşkilatı). Bursa: Ekin Kitabevi Yayınları.

Hofmann, S., Beverungen, D., Räckers, M. ve Becker, J. (2013). What makes local governments' online communications successful? Insights from a multi-method analysis of Facebook. Government Information Quarterly, 30 (4),387-396. doi:https://doi.org/10.1016/j.giq.2013.05.013.

KL - Local Government Denmark. Municipal Responsibilities. 14.01.2020 tarihinde https://www.kl.dk/english/municipal-responsibilities/ adresinden erişildi.

Mahmood, M., Weerakkody, V. ve Chen, W. (2019). The role of information and communications technology in the transformation of government and citizen trust. International Review of Administrative Sciences, 1-20. doi:https://doi.org/10.1177/0020852318816798.

Muratpaşa Belediyesi. Muratpaşa, Çevreci Komşu Kart'la kazanuyor. (2018). Muratpaşa Belediyesi. 22.01.2020 tarihinde https://muratpasa-bld.gov.tr/haber/50409/3/muratpasa-cevreci-komsu-kartla-kazaniyor adresinden erişildi. 
Pieterson, W. (2010). Citizens and service channels: channel choice and channel management implications. International Journal of Electronic Government Research, 6 (2), 3753.

Pieterson, W. ve Ebbers, W. (2008). The use of service channels by citizens in the Netherlands: implications for multi-channel management. International Review of Administrative Sciences, 74(1), 95-110. doi:https://doi.org/10.1177/0020852307085736.

Plattfaut, R., Kohlborn, T., Hofmann, S., Beverungen, D., Niehaves, B., Räcker, M. ve Becker, J. (2013). Unravelling (E-)Government Channel Selection: A Quantitative Analysis of Individual Customer Preferences in Germany and Australia. 46th Hawaii International Conference on System Sciences, Wailea, Maui, HI, 1983-1991. doi: 10.1109/HICSS.2013.585.

Reddick, C. G., Abdelsalam, H. M. E. ve Elkadi, H. A. (2012). Channel choice and the digital divide in e-government: the case of Egypt. Information Technology for Development, 18 (3), 226-246.

Ruige, A, Üskent, S. ve Micka, P. (2014). Yönetişim ve katılım: Etkili Katılım için araçlar, yöntemler, mekanizmalar, yönetişim ve katılım rehberi. Stratejik Yerel Yönetişim Projesi, İçişleri Bakanlığı Mahalli İdareler Genel Müdürlüğü

Şarbak, Z. (2017). Türkiye'de yerel yönetimler. (2. bs.). Ankara: Türkiye Belediyeler Birliği. Şengül, H. T. (2001). Kentsel çelişki ve siyaset - kapitalist kentleşme süreçleri üzerine yazılar. İstanbul: WALD Yayınları.

T.C. Anayasası (1982). 06.01.2020 tarihinde https://www.tbmm.gov.tr/anayasa/anayasa_2018.pdf adresinden erişildi.

Tekeli, İ. (1977). Belediyeler ve kent yönetiminin sınıfsal yapısı. Mimarlık, 77(1), 32-34.

Tekeli, İ. (2009). Cumhuriyetin belediyecilik öyküsü (1923-1990). İstanbul: Tarih Vakfı Yurt Yayınları.

Türkiye Belediyeler Birliği (TBB). Functions of Municipalities. 06.01.2020 tarihinde https://www.tbb.gov.tr/en/local-authorities/functions-of-municipalities/ adresinden erişildi.

Vivier, E., Seabe, D., Wentzel, M. ve Sanchez, D. (2015). From information to engagement: Exploring communication platforms for the government-citizen interface in South Africa. African Journal of Information and Communication. 15, 81-92. doi:10.23962/10539/20332. 